\title{
USE OF MICROMACHINING TO SHAPE THE STRUCTURE AND ELECTRICAL PROPERTIES OF THE FRONT ELECTRODE OF A SILICON SOLAR CELL
}

\author{
UPORABA MIKROOBDELOVANJA ZA OBLIKOVANJE \\ STRUKTURE IN ELEKTRIČNIH LASTNOSTI PREDNJE \\ ELEKTRODE SILICIJEVE SONČNE CELICE
}

\author{
Małgorzata Musztyfaga-Staszuk \\ Silesian University of Technology, Welding Department, Konarskiego Street 18a, 44-100 Gliwice, Poland \\ malgorzata.musztyfaga@polsl.pl \\ Prejem rokopisa - received: 2014-07-07; sprejem za objavo - accepted for publication: 2014-09-05
}

doi: $10.17222 / \mathrm{mit} .2014 .099$

\begin{abstract}
The aim of the work was to study the influence of the front-electrode structure produced with the conventional and unconventional techniques on the electrical properties of silicon solar cells. The investigations were performed on a front electrode produced with the conventional sintering technique in an infrared conveyor furnace and an electrode produced with the unconventional technique of selective laser sintering with a paste based on a silver powder. The investigations of the structure and properties of the front electrodes as well as the electrical properties of the obtained silicon solar cells were performed. The investigations were done on monocrystalline silicon wafers. A special test system was prepared to evaluate the contact resistance of the silver-silicon contact. The front contacts were formed on the surfaces with different morphologies. An optimum model of the front electrode and the area of its connection with the substrate is presented, enabling the best electrical properties of photovoltaic cells. The paper gives a broad general knowledge necessary for solving the problems relating to solar cells

Keywords: nanosciences and nanotechnologies, selective laser sintering, silicon solar cell, contact resistance, TLM method
\end{abstract}

Namen dela je bil študij vpliva strukture sprednje elektrode, proizvedene po običajni in neobičajni metodi, na električne lastnosti silicijeve sončne celice. Preiskave so bile izvršene na sprednji elektrodi, izdelani po običajni metodi z infrardečim sintranjem na traku kontinuirne peči, in na elektrodi, izdelani z neobičajno tehniko selektivnega laserskega sintranja s pasto na osnovi srebra v prahu. Izvršene so bile preiskave strukture in lastnosti sprednje elektrode, kot tudi električne lastnosti dobljene silicijeve sončne celice. Preiskave so bile izvršene na monokristalni silicijevi rezini. Za oceno upornosti stika srebro-silicij je bil pripravljen poseben preizkusni sistem. Sprednji kontakt je bil pripravljen na površini z različno morfologijo. Predstavljena sta optimalni model sprednje elektrode in področje njenega stika s podlago, ki omogoča najboljše električne lastnosti fotovoltaične celice. Članek daje izhodišča za novo znanje pri reševanju problemov s področja sončnih celic.

Ključne besede: nanoznanost in nanotehnologija, selektivno lasersko sintranje, silicijeva sončna celica, upornost stika, TLM-metoda

\section{INTRODUCTION}

The whole industry and the life of the average man depend on the electrical energy. One of the methods to acquire the solar energy is the use of photovoltaic cells. For the production of photovoltaic cells we can apply many semiconductor materials, such as silicon (polyand monocrystalline, amorphous), gallium arsenide, cadmium telluride, cadmium-copper selenide, indium phosphide and conducting polymers. ${ }^{1-3}$ For example, monocrystals have very good properties and good cell efficiency in the mass production (14-18\%), but they are expensive. Therefore, research studies are being carried out to find new solutions involving the production technology and indispensable tools used for this purpose, aiming to raise the cell efficiency with the minimum reduction of the material consumption., ${ }^{1,4-8}$

One of such emerging production operations involving photovoltaic cells is the deposition of electrical contacts. As it has been found by numerous research studies, the electrode coating should satisfy different requirements to ensure a low resistance of the interface zone between the electrode and the substrate. A proper selection of the material (for the electrode and the substrate), the conditions of its fabrication, the shape and size of the electrode, the adhesion of the electrode to the substrate and the substrate morphology are of particular importance. In order to improve the electrical properties

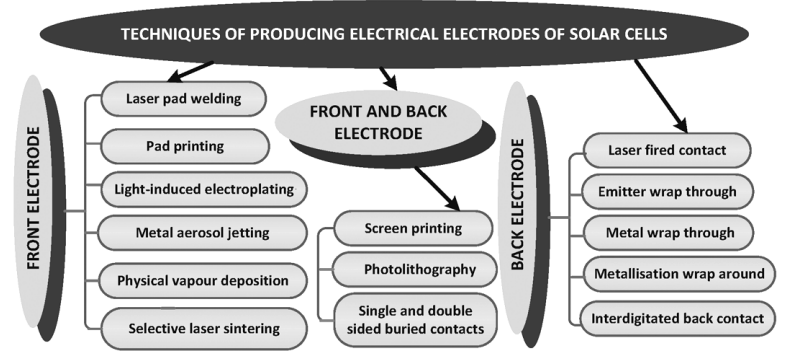

Figure 1: Classification of front and back electrodes 9 Slika 1: Klasifikacija prednje in zadnje elektrode ${ }^{9}$ 


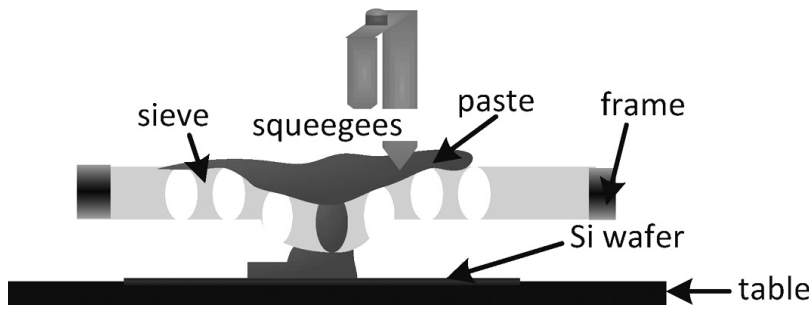

Figure 2: Screen-printing method ${ }^{10}$

Slika 2: Metoda sitotiska ${ }^{10}$

of the front electrode, various fabrication techniques have already been analyzed (Figure 1), including different imprint techniques and the final connection of the electrode with the substrate surface. This paper summarizes the recent investigations into the front-side metallization achieved with the conventional technique (Figure 2) in comparison with an unconventional technique (Figure 3). ${ }^{9-11}$

\section{STUDY MATERIAL AND SAMPLE PREPARATION}

The investigations were done on monocrystalline silicon wafers. The basic parameters of these wafers were: the conductivity - the p type; the dopant element boron; the thickness $-(200 \pm 20) \mu \mathrm{m}$ and $(330 \pm 10) \mu \mathrm{m}$; the resistivity $-1-2 \Omega \mathrm{cm}$ and $\approx 1 \Omega \mathrm{cm}$; the area -25 $\mathrm{cm}^{2}$. Micromachining was applied to a wafer with a thickness of $\approx 330 \mu \mathrm{m}$, and during the co-firing in a furnace its thickness was $\approx 200 \mu \mathrm{m}$. For the fabrication of front electrodes, silver pastes were applied (Table 1), experimentally elaborated on the basis of a silver powder with a granulation $<40 \mathrm{~nm}$ (Figure 4), an organic carrier and silicon dioxide. The technology to produce solar

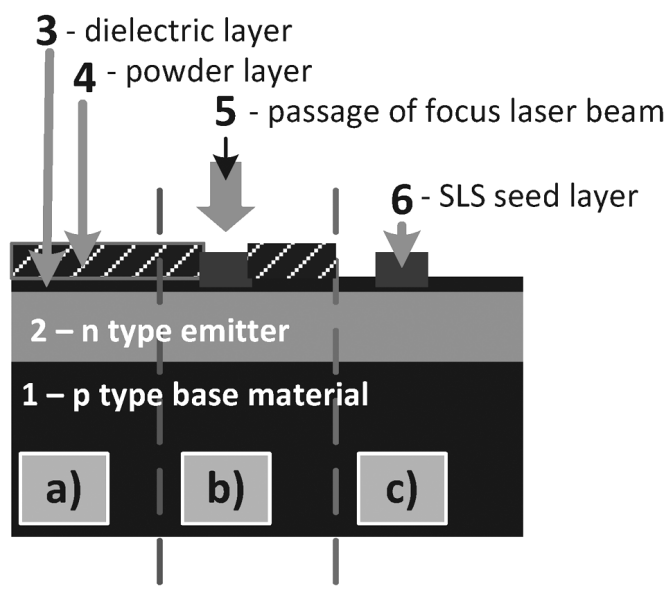

Figure 3: Technology for the formation of front contacts using selective laser sintering (SLS): a) a metallic powder is applied to the Si wafer, b) a laser beam heats the powder locally and melts it into metal lines on the top of the $\mathrm{Si}$ wafer, c) the excess metallic powder is moved into the container ${ }^{9,11}$

Slika 3: Tehnologija tvorbe prednjih kontaktov s selektivnim laserskim sintranjem (SLS): a) kovinski prah na Si-rezini, b) laserski žarek ogreva prah lokalno in napravi talilne linije na Si-rezini, c) presežek kovinskega prahu se odvede $\mathrm{v}$ zbiralnik $^{9,11}$

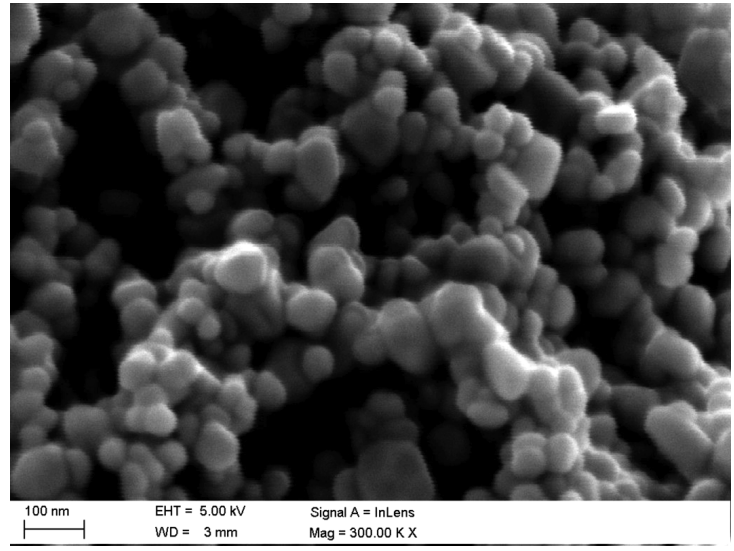

Figure 4: SEM micrograph of silver-powder granulation $<40 \mathrm{~nm}$ Slika 4: SEM-posnetek granulacije prahu srebra $<40 \mathrm{~nm}$

Table 1: Paste prepared and used for the front metallization

Tabela 1: Pasta, pripravljena in uporabljena pri sprednji metalizaciji

\begin{tabular}{|c|c|c|}
\hline Paste symbol & Powder size & $\begin{array}{c}\text { Applied method (con- } \\
\text { vectional, unconventional) }\end{array}$ \\
\hline $\mathrm{H} 1$ & $<40 \mathrm{~nm}$ & Unconventional \\
\hline $\mathrm{H} 2$ & $<40 \mathrm{~nm}$ & Convectional \\
\hline
\end{tabular}

cells was developed at the Institute of Metallurgy and Materials Science in Krakow (Poland). Front contacts were formed on the surfaces of solar cells with various morphologies (textured with a deposited antireflection layer and textured without a deposited antireflection layer, non-textured with a deposited antireflection layer and non-textured without a deposited antireflection layer). Two special test electrode systems were prepared with the screen-printing method in order to determine the suitability of the silver pastes using the two techniques and to evaluate the contact resistance of the metal semiconductor junction, where the sizes of the front paths were $X=2 \mathrm{~mm} \times 10 \mathrm{~mm}$ (width $\times$ length), with the distances between them being $(20,10,5$ and 2.5$) \mathrm{mm}$, and $Y$ $=5 \mathrm{~mm} \times 10 \mathrm{~mm}$ (width $\times$ length), with the distances between them being $(1,2,4$ and 8$) \mathrm{mm}$.
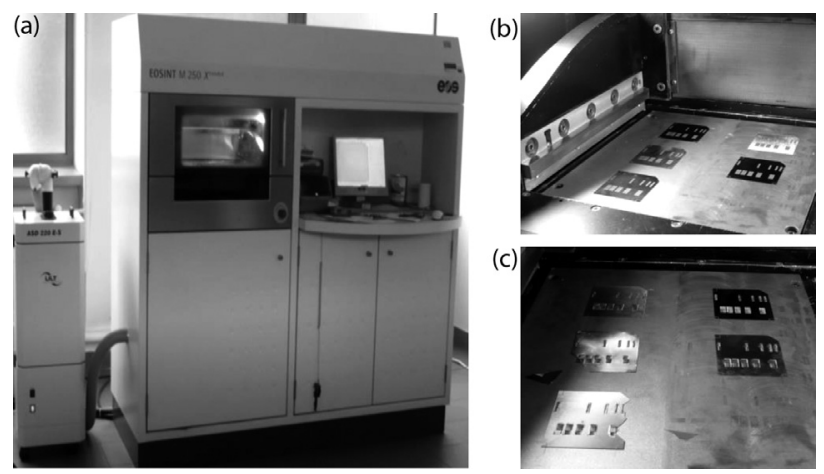

Figure 5: Laser micro-treatment system: a) the EOSINT M 250 Xtended device was equipped with $\mathrm{CO}_{2}$ laser, b) samples before SLS in a working chamber, c) samples after SLS in a working chamber ${ }^{12}$ Slika 5: Sistem za mikroobdelavo z laserjem: a) naprava EOSINT M 250 Xtended je opremljena s $\mathrm{CO}_{2}$-laserjem, b) vzorci pred SLS v delovni komori, c) vzorci po SLS v delovni komori ${ }^{12}$ 
The laser micromachining conditions for the test electrode system $X, Y$ were selected for the selective laser sintering (Table 2). Figure 5 presents the laser micro-treatment system. ${ }^{12}$

Table 2: Conditions of laser micro-treatment of test electrodes of solar cells

Tabela 2: Razmere pri laserski mikroobdelavi preizkusnih elektrod sončnih celic

\begin{tabular}{|c|c|c|c|}
\hline $\begin{array}{c}\text { Paste } \\
\text { symbol }\end{array}$ & $\begin{array}{c}\text { Height of printed } \\
\text { front electrode }(\mu \mathrm{m})\end{array}$ & $\begin{array}{c}\text { Feed rate of laser } \\
\text { beam, }(v /(\mathrm{mm} / \mathrm{s}))\end{array}$ & $\begin{array}{c}\text { Laser beam } \\
(P / \mathrm{W})\end{array}$ \\
\hline H1 & 15 & $38,41,43$ & 50 \\
\hline
\end{tabular}

Table 3 presents some solar cells with the test electrode system $X, Y$, prepared for co-firing on conveyor belt IR, which was equipped with fitted tungsten-filament lamps, heating both the top and the bottom of the belt.

Table 3: Conditions of co-firing test electrodes of solar cells in the furnace

Tabela 3: Razmere pri žganju preizkusnih elektrod sončne celice $v$ peči

\begin{tabular}{|c|c|c|}
\hline Paste symbol & $\begin{array}{c}\text { Height of printed front } \\
\text { electrode }(\mu \mathrm{m})\end{array}$ & $\begin{array}{c}\text { Temperature in } \\
\text { zone III }\left({ }^{\circ} \mathrm{C}\right)\end{array}$ \\
\hline \multirow{3}{*}{$\mathrm{H} 2$} & \multirow{3}{*}{15} & 830 \\
\cline { 3 - 3 } & & 860 \\
\cline { 3 - 3 } & & 890 \\
& & 920 \\
& & 945 \\
\hline
\end{tabular}

Comparative investigations were performed on the electrical parameters such as the contact resistance, the specific contact resistance $\left(\rho_{\mathrm{c}}\right)$ and the transfer length $\left(L_{\mathrm{T}}\right)$ of the front electrodes of the solar cell using the traditional transmission-line-model method (TLM), based on a simultaneous extraction of the electric-current signal $(I)$ between the chosen front contacts and the potential difference $(U)$ intrinsically generated on them. The resistance $R$ was measured and a graph of $R$ against the distance was constructed. From the obtained data the parameters $R_{\mathrm{c}}, \rho_{\mathrm{c}}, L_{\mathrm{T}}$ were determined. The topographies of both the surfaces and the cross-sections of the front contacts were observed, using a SEM microscope (Zeiss Supra 35). Also, the topography of the textured monocrystalline silicon wafer was observed, using an atomicforce microscope (Park Systems XE 100). The medium size of the pyramids was measured using this microscope.

\section{RESULTS AND DISCUSSION}

The optimum test electrode was selected by the researcher taking into account the paste composition (including the powders with different granulations), the conditions of its fabrication, its shape and size, the lowest resistance value of the joint between the electrode and the substrate, the substrate morphology and the quality of the structure obtained on the surface and cross-section.

The performance of the front electrodes of the semiconductors can be studied by measuring the value of specific contact resistance $\rho_{\mathrm{c}}$ (characterized by the connection zone between the contact and the silicon substrate and the regions directly under and below the surface of the phase separation), contact resistance $R_{\mathrm{c}}$ (Figure 6) and transfer length $L_{\mathrm{T}}$. These parameters can be specified with a method based on TLM. The specific contact resistance of the front electrode for given current values of $(10,30,50) \mathrm{mA}$ were determined, depending on the conditions of the unconventional (Figure 7a) and conventional (Figure 7b) methods.

The unconventional method: With the investigations based on the electrical properties, using the TLM method, it was found that the smallest specific-contactresistance values of test electrodes $X, Y$ were $0.1-12$ $\Omega \mathrm{cm}^{2}$ and $0.4-2.2 \Omega \mathrm{cm}^{2}$, respectively, for the solar cells with different morphologies. The minimum value of the specific contact resistance was obtained for test electrode system $X\left(0.1 \Omega \mathrm{cm}^{2} ; 0.2 \Omega \mathrm{cm}^{2}\right)\left(\min . \rho_{\mathrm{c}}=0.1\right.$
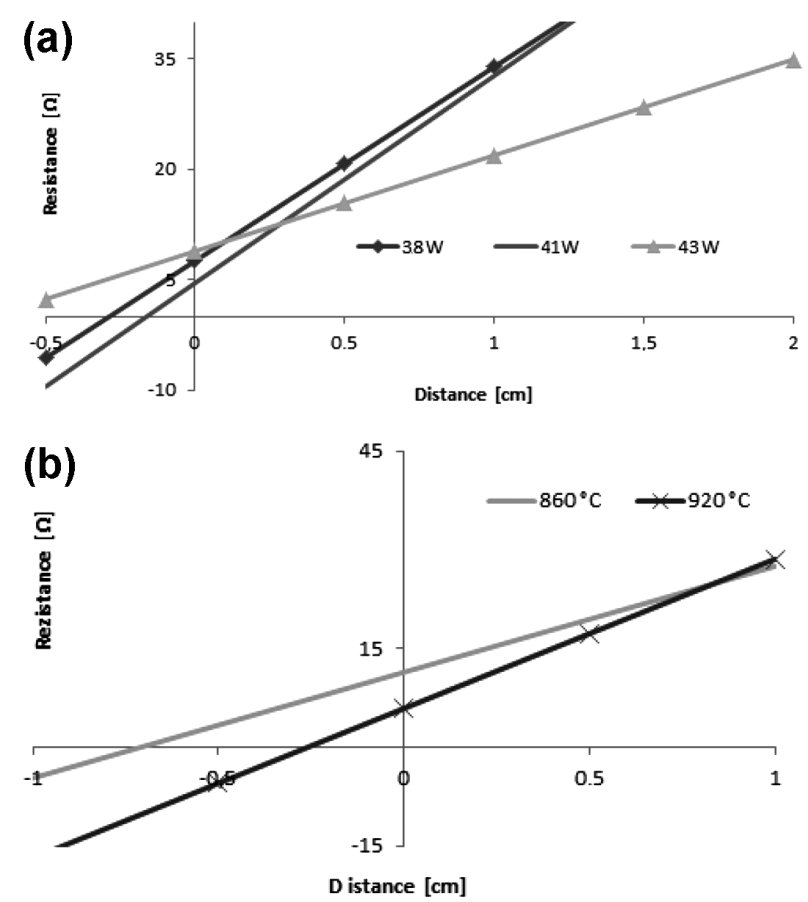

Figure 6: Dependence of the contact resistance of the emitter with varying distance $Y$ between the adjacent special test electrode systems: a) on the laser-beam power for paste $\mathrm{H} 1$ on a silicon solar cell with ARC layer and with the texture selectively laser sintered with the feed rate of $50 \mathrm{~mm} / \mathrm{s}, \mathrm{b}$ ) on the co-fired temperature for paste $\mathrm{H} 2$ on a silicon solar cell without ARC layer and with texture (the example with the smallest parameters $-\rho_{\mathrm{c}}, L_{\mathrm{T}}$ and $R_{\mathrm{c}}-$ for a given value of the current: $10 \mathrm{~mA}$ )

Slika 6: Odvisnost upornosti spoja od oddajnika pri spreminjanju razdalje $Y$ med mejnima elektrodnima sistemoma: a) na moč laserskega žarka pri pasti $\mathrm{H} 1$ na silicijevo sončno celico $\mathrm{z}$ ARC-nanosom in $\mathrm{s}$ teksturo, selektivno lasersko sintrano s hitrostjo podajanja $50 \mathrm{~mm} / \mathrm{s}, \mathrm{b}$ ) na temperaturo žganja pri pasti $\mathrm{H} 2$ na silicijevo sončno celico brez ARC-nanosa in $\mathrm{s}$ teksturo (izbran primer za najmanjše parametre: $\rho_{\mathrm{c}}$, $L_{\mathrm{T}}$ in $R_{\mathrm{c}}$, pri dani vrednosti toka: $10 \mathrm{~mA}$ ) 

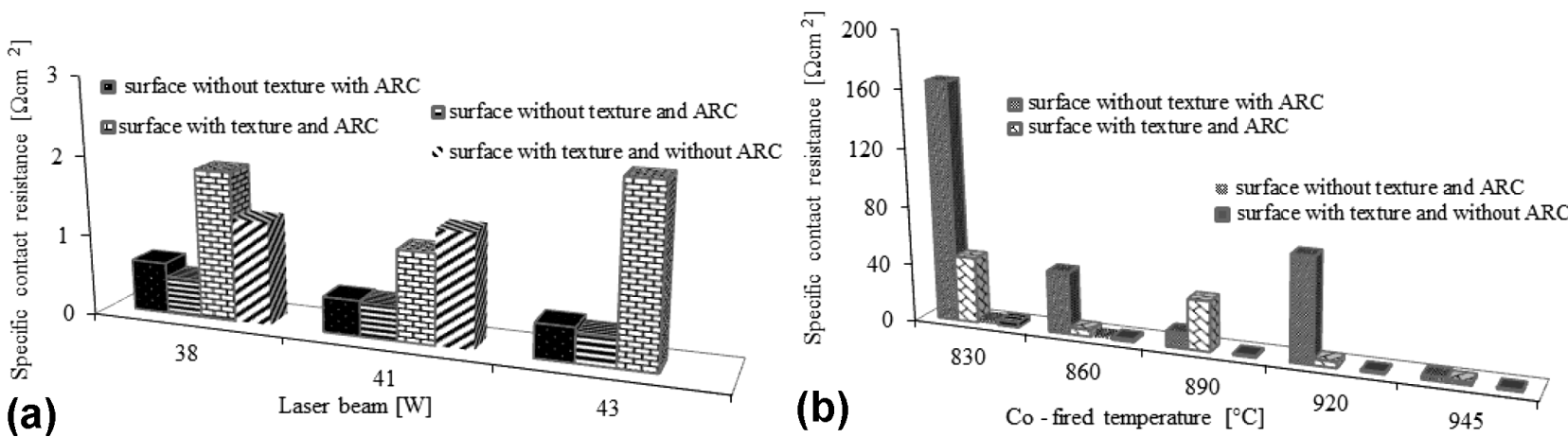

Figure 7: Specific contact resistance depending on: a) laser micro-treatment conditions where electrodes were obtained from paste H1, b) conditions of co-firing in the furnace where electrodes were obtained from paste $\mathrm{H} 2$ (the example for test electrode system $Y$ )

Slika 7: Specifična upornost kontakta, odvisna od: a) razmer pri laserski mikroobdelavi, kjer so bile elektrode pripravljene iz $\mathrm{H} 2$-paste, b) dodatno žgano v peči, elektrode pripravljene s H2-pasto (izbrani vzorec za preizkus sistema elektrod $Y$ )

$\left.\Omega \mathrm{cm}^{2}, P=41 \mathrm{~W}\right)$ on the substrate without texture and the $\mathrm{TiO}_{x}$ coating of the solar cell. In the case of test electrode system $Y$ the specific contact resistance was 0.4-2.2 $\Omega \mathrm{cm}^{2}$. The minimum value of the specific contact resistance was obtained for test electrode system $Y\left(0.4 \Omega \mathrm{cm}^{2} ; 0.5 \Omega \mathrm{cm}^{2}\right)\left(\min . \rho_{\mathrm{c}}=0.4 \Omega \mathrm{cm}^{2}, P=41\right.$
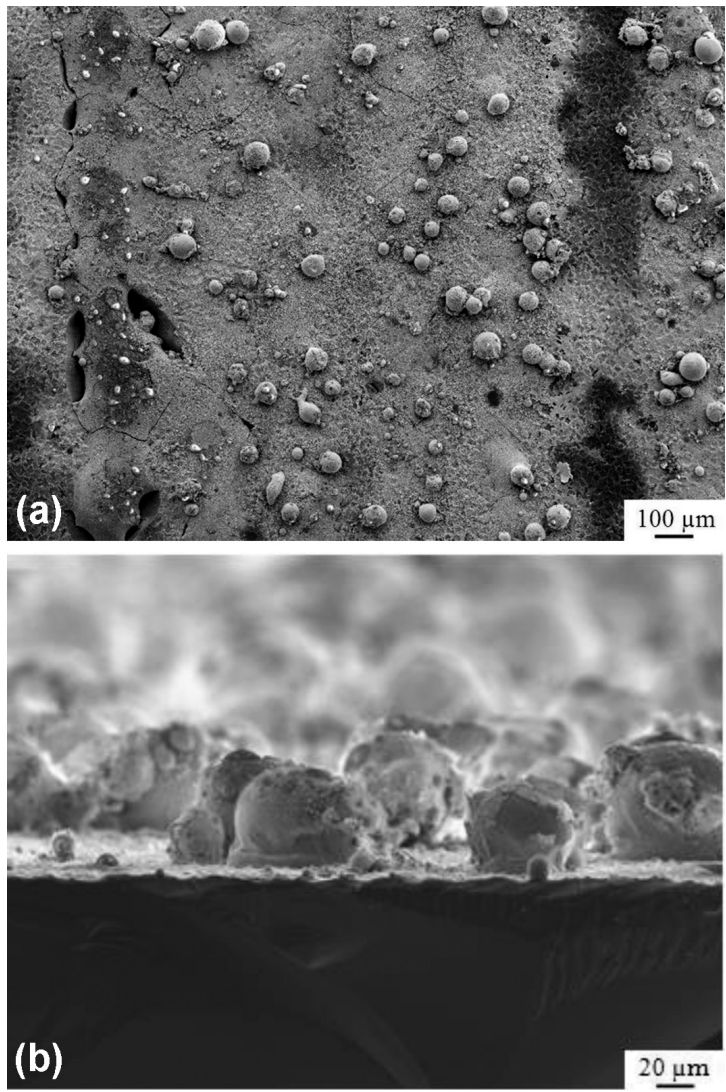

Figure 8: SEM of the surface layer obtained from paste $\mathrm{H} 1$ on the silicon surface and deposited with the screen-printing method and laser sintered with a laser-beam feed rate of $50 \mathrm{~mm} / \mathrm{s}$ and the maximum laser-beam power of $41 \mathrm{~W}$ : a) topography image, b) fracture image

Slika 8: SEM-posnetka površine, nastale iz H1-paste na površini silicija in nanesene $\mathrm{z}$ metodo sitotiska, lasersko sintrano $\mathrm{z}$ laserskim žarkom s podajanjem $50 \mathrm{~mm} / \mathrm{s}$ in največjo močjo laserja $41 \mathrm{~W}$ : a) posnetek topografije, b) posnetek preloma
W) on the substrate without texture and the $\mathrm{TiO}_{x}$ coating of the solar cell.

The conventional method: With the investigations based on the electrical properties, using the TLM method, it was found that the smallest specific-contact-resistance values of test electrode system $X, Y$ were $1.8-86.8 \Omega \mathrm{cm}^{2}, 1.1-165.6 \Omega \mathrm{cm}^{2}$, respectively, for the
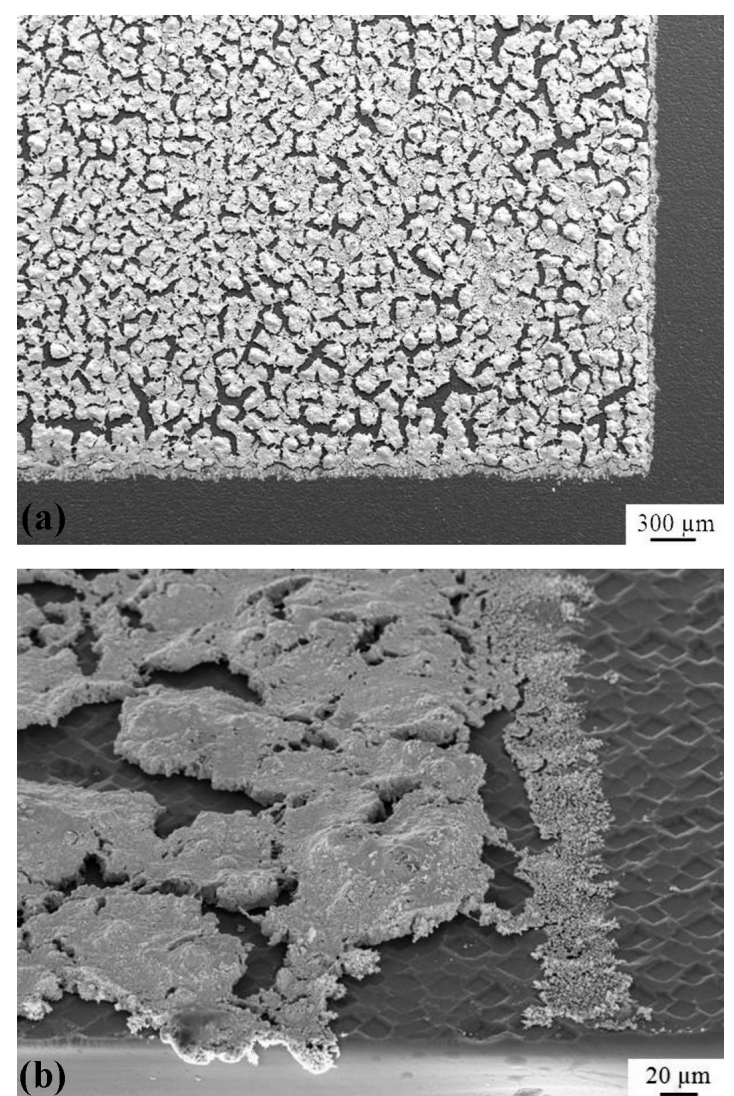

Figure 9: SEM of front contact layer obtained from paste $\mathrm{H} 2$ and co-fired in the conveyor furnace at $945{ }^{\circ} \mathrm{C}$ on Si substrate without texture and ARC layer: a) topography image, b) fracture image

Slika 9: SEM-posnetka sprednjega sloja kontakta, nastalega iz $\mathrm{H} 2$-paste in pri žganju v peči s transporterjem pri $945^{\circ} \mathrm{C}$ na podlagi iz $\mathrm{Si}$, brez teksture in ARC-nanosa: a) posnetek topografije, b) posnetek preloma 


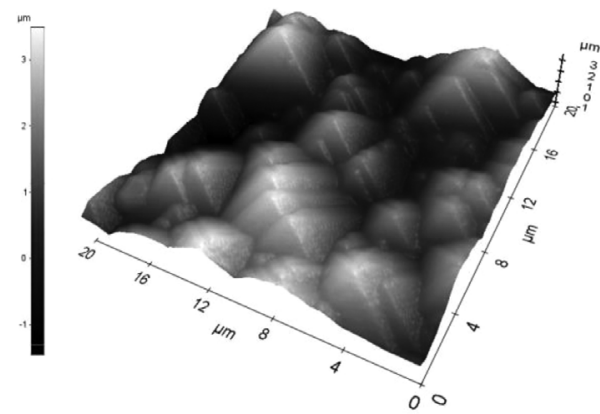

(a)
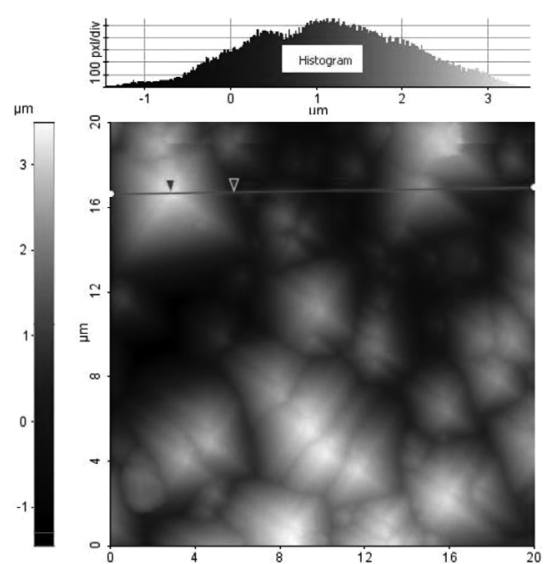

(b)

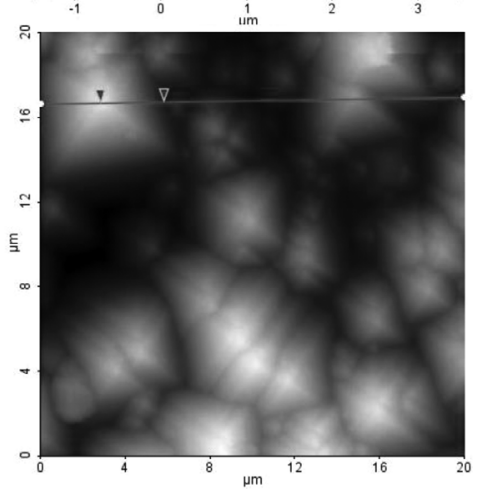

Figure 10: Topography of the textured surface of a monocrystalline solar wafer with a thickness of $\approx 330 \mu \mathrm{m}$ (AFM)

Slika 10: Topografija teksturirane površine monokristalne solarne rezine $\mathrm{z}$ debelino $\approx 330 \mu \mathrm{m}(\mathrm{AFM})$

solar cells with different morphologies. The minimum value of the specific contact resistance was obtained for test electrode system $X\left(1.8 \Omega \mathrm{cm}^{2} ; 2.9 \Omega \mathrm{cm}^{2}\right)$ (min. $\rho_{\mathrm{c}}$ $=1.8 \Omega \mathrm{cm}^{2}, 860{ }^{\circ} \mathrm{C}$ ) on the substrate with texture and without the $\mathrm{TiO}_{x}$ coating of the solar cell. In the case of test electrode system $Y$ the specific contact resistance was 1.1-165.6 $\Omega \mathrm{cm}^{2}$. The minimum value of the specific contact resistance was obtained for test electrode system $Y\left(1.1 \Omega \mathrm{cm}^{2} ; 2.3 \Omega \mathrm{cm}^{2}\right)\left(\min . \rho_{\mathrm{c}}=1.1 \Omega \mathrm{cm}^{2}\right.$, $945^{\circ} \mathrm{C}$ ) on the substrate with texture and without the $\mathrm{TiO}_{x}$ coating of the solar cell.

On the basis of these two series, the optimum model structure (the $Y$ test electrode system) for the front electrode and the area of its connection with the substrate was found, exhibiting the most satisfactory electrical properties of the photovoltaic cells. Electrical properties of an electrode are closely dependent on the use of particular components of the pastes from which they are made. The conductivity of the investigated silver paste depends on the granulation, the particle shape and the quantity of the powder in its composition. The ceramic glaze combines base-material particles between each other and with the substrate; the rest composes the mixture of the ceramic glaze, which gives the paste a proper viscosity.

With respect to the quality of the test-electrodesystem structure, we found a partial evaporation of an electrode, the melting of the elements, and the areas of a fully exposed silicon substrate of the electrode (Figure 8a). The connections of the electrodes obtained from the H1 paste, based on silver nanopowder are pointwise, and the only places close to a continuous connection (Figure 8b). Figure 9a presents a compound structure containing numerous cracks on the entire electrode surface. This electrode exhibited a porous structure and the porosity grade depended on the co-firing temperature (Figure 9b).

In the case of the silicon-substrate morphology, it was found that it has a significant influence on obtaining the minimum resistance values of the electrodes made with selective laser sintering from paste H1. The influence is bigger for the substrate with texture than for the one without texture, which is probably connected with the occurrences of the empty areas under the contacts due to different thicknesses of the pyramids with textured surfaces that we can find in the literature. The topographies of the silicon wafers with texture were observed with the atomic-force microscope. The medium thickness of the pyramids was found to be $3 \mu \mathrm{m}$ (Figure 10), which is consistent with the literature, where the thickness of the pyramids with textured surfaces for $\mathrm{Si}$ (100) is in the range from $3 \mu \mathrm{m}$ to $9 \mu \mathrm{m}$.

\section{CONCLUSION}

The investigation studies the fabrication conditions for the front electrodes based on silver powders of various granulations and made with the laser technique, which have become indispensable elements of modern photovoltaic technology. This is an innovative contribution to the solution of the present photovoltaic problems. Hence, the results of the work provide a kind of a guideline for other research workers indicating the focus for further studies.

Based on the results, the following optimum process parameters for manufacturing front electrodes of silicon solar cells were selected: the laser beam $(41 \mathrm{~W})$, the substrate (without texture and antireflection coating) of a solar cell, the minimum value of the specific contact resistance $\left(0.4 \Omega \mathrm{cm}^{2}\right)$ and the paste composition prepared from a nanopowder (H1). It was established that a non-uniformly melted structure caused a pointwise adhesion to the silicon substrate.

\section{Acknowledgements}

The authoress thanks Prof. L. A. Dobrzanski for valuable guidance during the realisation of this work.

\section{REFERENCES}

${ }^{1}$ P. Panek, M. Lipiński, E. Bełtowska-Lehman, K. Drabczyk, R. Ciach, Opto-electronics Review, 11 (2003), 269-275

${ }^{2}$ W. Smolec, Photothermal conversion of solar energy, PWN, Warsaw 2000 
${ }^{3}$ Directive 2009/28/EC of the European Parliament and of the Council on the promotion of the use of energy from renewable sources and amending and subsequently repealing Directives 2001/77/EC and 2003/30/EC

${ }^{4}$ M. T. Sarniak, The basics of photovoltaics, Warsaw University of Technology Publishing, Warsaw 2008

${ }^{5}$ T. Rodacki, A. Kandyba, The energy processing in a solar station, Silesian University of Technology, Gliwice 2000 (in Polish)

${ }^{6}$ Z. M. Jarzębski, Solar energy: photovoltaic conversion, PWN, Warsaw 1990

${ }^{7}$ L. A. Dobrzański, Engineering materials and materials design, Fundamentals of materials science and physical metallurgy, WNT, Warsaw - Gliwice 2006
${ }^{8}$ D. Janicki, Solid State Phenomena, 199 (2013), 587-592, doi:10.4028/www.scientific.net/SSP.199.587

${ }^{9}$ L. A. Dobrzański, M. Musztyfaga, Journal of Achievements in Materials and Manufacturing Engineering, 48 (2011) 2, 115-144

${ }^{10}$ L. A. Dobrzański, M. Musztyfaga, A. Drygała, P. Panek, Journal of Achievements in Materials and Manufacturing Engineering, 41 (2010) 1-2, 57-65

${ }^{11}$ A. Lisiecki, Proc. of SPIE, Vol. 8703, Laser Technology 2012: Applications of Lasers, 87030S (2013), doi:10.1117/12.2013429

${ }^{12}$ www.ios.krakow.pl 